\title{
Analysis of the IPO Valuation Premium Puzzle: the Factor of Information Asymmetry
}

\author{
Dmytro Osiichuk*
}

\begin{abstract}
Based on existing empirical evidence and the theoretical model developed by Akerlof (1970), the paper offers an explanation of the IPO valuation premium puzzle. When choosing between an IPO and a sellout as possible options of going public, an increasing number of companies prefer the latter despite the fact that the IPO potentially offers higher valuation premiums. The conclusions derived by means of a critical review of the empirical literature suggests that this phenomenon is mainly shaped by the factor of information asymmetry, which prompts the analogy with the 'lemons' market. Akerlof's model helps clarify the IPO valuation premium puzzle, however, some important deviations from the predictions of the normative analysis are observed in practice, which, as demonstrated in the paper, can be explained by the influence of behavioural factors. We postulate that the validity of the theoretical models, which explain the valuation puzzles, hinges upon the assumptions regarding market efficiency and rationality of the market participants. We systematize those assumptions and make conclusions regarding their relevance in case of the phenomenon in question. The paper explains how the market mechanisms, for example, the dual-track IPOs, allow overcoming the problem of information asymmetry and, possibly, eliminating the valuation anomalies.
\end{abstract}

Keywords: IPO valuation premium puzzle, acquisition, information asymmetry

\section{Introduction}

An IPO and a sell-out to a public company constitute the principal ways of ownership transfer contemplated by the owners of private companies. Having compared the outcomes of each of the two options Poulsen and Stegemoller (2008) concluded, that companies choosing the IPO record higher valuation multiples than those having chosen the acquisition by a public company. This conclusion prompted a discussion over the existence of an extra IPO valuation premium, which suggests that a private company seeking to maximize value for the shareholders should opt for an IPO. However, in practice an ever increasing number of firms choose the sell-out (Gao et al., 2011). This observation constitutes the basis of the IPO valuation premium puzzle (Bayar \& Chemmanur, 2012). An analysis of the relevant empirical evidence, regulatory and technical framework of IPOs and acquisitions allow to suggest that information asymmetry is the distinguishing feature which may serve as a starting point for a further search of the factors shaping the phenomenon of the analysed valuation puzzle.

\footnotetext{
*mgr Dmytro Osiichuk, Akademia Leona Koźmińskiego w Warszawie, e-mail: dosiichuk@kozminski.edu.pl.
} 
Akerlof's (1970) seminal article on the relationship between quality and uncertainty provides the theoretical background of the discussion and provides the foundations for a normative analysis: first, we will outline the predictions of the model, and then try to explain the deviations which appear in practice. Thereby, the paper represents an attempt to explain the IPO valuation premium puzzle by using information asymmetry. We establish, how the quality uncertainty may influence the choice between an IPO and a sell-out to a public company, and how behavioural biases distort the market equilibrium, which would have been reached under assumptions of market efficiency and investors' rationality. ACritical review of the empirical literature is chosen as a principal research method allowing to supplement the argumentation with high-quality empirical evidence.

The paper is structured as follows: first, the theoretical framework of the analysis is presented; secondly, the derived conclusions are confronted with the empirical evidence and the deviations from the theoretical assumptions are outlined; and finally, the paper presents the behavioural analysis of the valuation anomalies, which cannot be explained within the proposed theoretical framework.

\section{Theoretical Background: The Market for 'Lemons'}

Akerlof (1970) analysed the influence of uncertainty on the outcome of the market mechanism using the example of the market for used cars: asymmetry of information, which causes the buyer to be unable to distinguish between good and bad cars ('lemons'), results in a decrease of the expected average quality of the offered cars, which, in turn, reduces the reservation prices of the buyers to the level below the expectations of the owners of good cars. As a consequence, the owners of the good quality cars leave the market. Due to the same reason, i.e. information asymmetry, the new cars are sold at a higher price than the used cars. The buyer pays a premium for eliminating uncertainty and for assurance of the car's quality.

The mechanism of the sell-outs of private companies is quite similar to the market for used cars. There is an apparent asymmetry of information between the owners of the private company and the management of the acquirer. Since usually acquisitions result in an almost complete transfer of ownership, the owners of the acquiree are interested in maximizing the payoff, which makes them recur to techniques of window dressing and creative accounting aimed at exploiting the advantages of information asymmetry (which remains an issue despite the application of rigorous due diligence procedures).

Following the logic of Akerlof's model (1970), the acquirers are aware that the acquiree may turn out to be a 'lemon' (i.e. an acquisition will be value-destructive), and reduce the price respectively so that it accounts for the risk incurred. The private companies with significant growth opportunities would find the offered price to be lower than the discounted free cash flow anticipated by the company, and would seek to eliminate the information asymmetry using the mechanism of IPO. Although IPO entails significantly higher costs 
(underwriting, advisory, prospects etc.), it allows to avoid the loss on the information asymmetry discount. The disclosure requirements are considerably more stringent for companies contemplating an IPO than in the case of an acquisition: the company must appoint independent members to the board of directors, establish an audit committee, and review the practices of corporate governance etc. By engaging an underwriter, the company attests to its commitment to pursue a value maximizing strategy. What is more, since the IPO typically results in only a partial transfer of ownership, the current owners of a company with good growth prospects would prefer to maintain control over the company after it goes public, which constitutes an additional signal that the company is likely to generate substantial value in future.

To conclude, the asymmetry of information makes that companies with relatively poorer growth potential ('lemons') opt for a takeover by a company or an investor, while private companies with good growth prospects choose going public through an IPO (ceteris paribus), which would ideally eliminate the asymmetry of information and help the owners get a significantly higher valuation premium than in the case of a sell-out. In terms of Akerlof's model the IPO market is similar to the market for new cars, which means that an IPO should provide a higher valuation premium than a sell-out to a public company, which is the essence of the IPO valuation premium puzzle.

Assuming that the parallel with Akerlof's market for 'lemons' is valid, we can proceed to the normative analysis and make some predictions which will be further tested against the empirical evidence. All the conjectures are based upon the ceteris paribus assumption.

First of all, if our line of reasoning is correct, the companies opting for a sell-out should have a worse operating performance record prior to the transaction, than companies choosing an IPO. At the same time, companies which choose to go public through an IPO should presumably have an established competitive advantage, better growth opportunities and a better chance to increase and solidify their market share than those opting for an acquisition. To put it simply, IPOs are 'plums' which were forced out of the used cars market due to prevalent information asymmetry. As a consequence, the companies choosing a sell-out are much more likely to be 'lemons'.

The second conjecture derived from the developed theoretical framework: in the medium- and long-term perspective acquisitions tend to be value neutral or destroy the value of the acquiring company. On the contrary, firms which decided for an IPO should create value for the owners and should perform in accordance with the investors' expectations.

The third conjecture: in case of lack of growth opportunities (a company is a 'lemon'), current owners should be willing to sell out their entire stake in the company and, thus, should be more likely to prefer a takeover; otherwise (the company is a 'plum'), current owners should be willing to retain significant ownership interest in the company by making it public through an IPO, thereby signalling higher performance expectations (Leland, Pyle, 1977). 
The fourth conjecture is the corollary of the previous three: IPO should provide a higher valuation premium than an acquisition. This constitutes the base of the IPO valuation premium puzzle. Bayar and Chemmanur (2012) proved the existence of an IPO valuation premium, although they concluded, that in the long term the premium was decreasing for large companies initially backed by venture capital firms; at the same time, statistically significant premium was observed for small and medium-sized companies, which had the same propensity to go public as their acquired counterparts in the researched sample.

The next step consists in confronting the derived conjectures with the empirical evidence: by making a critical review of the empirical literature, we try to either substantiate or disprove the proposed conjectures, and explain any anomalies which depart from the elaborated theoretical framework.

\section{Performance Record of Private Companies Prior to an IPO or a Takeover: Empirical Evidence}

Based on an analysis of 2,269 IPOs and 2,017 acquisitions in the USA Bayar and Chemmanur (2012) established that (ceteris paribus): 1) companies choosing an IPO had statistically higher sales growth rates than companies opting for a sell-out prior to the transaction; 2) companies choosing an IPO were likely to operate in a more competitive environment (with a lower concentration index and lack of a dominant company) than companies that chose acquisition, which means that their chances of building a competitive advantage and solidifying market share were much higher; 3) companies in which retaining private control offered considerable benefits, were more likely to go public through an IPO, implying that owners were anticipating significant value creation after the transaction. These findings support the conjecture we made regarding the operating performance of the companies choosing between IPO and a sell-out prior to the transaction.

Poulsen and Stegemoller (2008) gathered samples of 1,074 IPOs and 735 acquisitions, making sure that they had comparable descriptive statistics. The analysis of the factors determining the choice between IPO and a sell-out revealed that companies with higher growth potential (assets growth rate, capital expenditures and revenues were used as proxies for potential growth opportunities) were more likely to go public.

Kim and Ritter (1999) divided the sample of IPOs into those of relatively young firms and older firms with established reputations: the young firms were found to have much higher valuation multiples, which may possibly be explained with the availability of growth options, while in the case of the older companies the cash flows were much more predictable resulting in lower multiples. The availability of attractive investment opportunities causes these companies to experience capital constraints. Same is true, although to a lesser extent, for the companies choosing to be taken over by a public company. However, the capital rationing in the latter case is caused by the fact that investment projects envisaged by the acquiree are in direct competition for resources with the projects of the acquirer. It was 
also found that companies opting for IPOs were less indebted than those choosing a sellout (Kim \& Ritter, 1999). It is worth underlining, that this conclusion is consistent with the agency theory, which states that companies with fewer investment opportunities are more likely to take on additional debt, which is supposed to exercise a disciplining effect and preclude the management from wasting generated cash flow on negative-NPV projects (Jensen, 1986). Thus, increase in a debt-to-equity ratio may indicate that the company is running out of attractive investment opportunities and may contemplate increasing dividend pay-outs to mitigate the agency risks.

Additionally, Poulsen and Stegemoller (2008) found that companies which chose to go public were characterized by significantly lower asymmetric information costs. It was argued that the degree of information asymmetry was much lower if: 1) the company had relatively higher profitability prior to the transaction; 2) the company possessed relatively more intangible assets; 3 ) the company was owned by a venture capitalist. The last point was tested separately revealing that venture capitalists were more likely to choose an IPO as an exit option for their company and retain control by selling only a minor portion of the company's equity, which is an argument substantiating our third conjecture.

The analysed empirical evidence proves the validity of our first conjecture, which posits that companies opting for an IPO have a better performance record than those choosing to be acquired (ceteris paribus).

\section{The Second Conjecture: Post-IPO and Post-Acquisition Performance Dynamics}

Jain and Kini (1994) found a significant decline in operating performance of the sampled companies in the post-IPO period. Although the major performance indicators (price-tobook value, price-to-earnings ratio, EPS growth rate) exceeded those of the peer group prior to the IPO, a subsequent decline was observed as soon as the companies went public. However, sales growth rates and capital expenditures remained at the same level. This suggests that the decline in operating performance was not caused by exhausting growth opportunities or by cutting back on investment expenses. In fact, the sales growth and value multiples remained higher than those of the non-listed competitors, however, a decline was observed compared to the pre-IPO levels. One possible explanation presented by Jain and Kini (1994) derives from the agency problem, which becomes especially acute when the incentives structure changes due to shifts in ownership. As a result, the growing agentprincipal conflict may cause the management to increase the consumption of perquisites or engage into value-destroying projects. Such an explanation is implausible if we assume that the institutional environment assures the efficiency of the corporate governance system and endows the shareholders with efficient tools of control and supervision. Following this assumption, any eventuality of irrational behaviour on the part of the management results in punitive actions (management replacement). 
Another possible explanation posits that managers tend to window-dress the performance figures of the company prior to IPO to be able to collect more cash. This hypothesis might be justified and would explain the disappointment of the investors after the operating figures deteriorate. Additionally, the moment of the IPO is usually chosen to coincide with the period of general stock market growth, which may additionally inflate the valuation (Ball et al., 2011). The above arguments strongly suggest that the phenomenon of operating performance decline in the post-IPO period has behavioural roots and stems from the irrationality of the stock market investors.

The hypothesis of the behavioural origin of the long-term underperformance of IPOs was advanced by Ang and Boyer (2009): the IPOs in 'new' industries, which have superior stock performance immediately after the issue, may have lower long-term performance due to the initial excitement on the market about the development opportunities of the new sector. The lack of possibility to reliably predict the performance of the new companies based on past accounting records may cause the initial valuation and value multiples to be misestimated. Additionally, Jain and Kini (1994) found a significant positive correlation between the post-IPO operating performance and the stake in ownership interest retained by the initial owners, which validates our third conjecture.

Research of the influence of market conditions on the choice between IPOs and acquisitions (Ball et al., 2011) proved that venture capitalists are most likely to choose an IPO when market participants are overly optimistic, which can explain the phenomenon of the dotcom bubble and a significant decline in the IPO dynamics after the outbreak of the subprime crisis.

To conclude, the empirical evidence suggests that IPOs are not performing in accordance with the expectations of the investors after the transaction. However, this phenomenon may be largely attributed to the influence of behavioural factors (behavioural deviations are not allowed for in Akerlof's model which assumes absolute rationality of the market participants).

While significant positive abnormal returns accruing to the target of acquisitions is not questioned (due to the significant amounts of acquisition premiums involved), the problem of the short- and long-term performance of the acquirer is much more difficult. Jensen and Ruback (1983) commented that the long-term underperformance of the acquirers expressed through a negative abnormal rate of return suggests that the potential synergies were significantly overestimated. Such a conclusion is clearly in contradiction with the hypothesis of market efficiency, implying that the problem may have behavioural causes.

Asquith (1983) found that the acquiring companies recorded statistically significant negative return on their shares in the period of 3 to 5 years following the acquisition.

In an extensive research covering the NYSE/AMEX acquisitions (Agrawal et al., 1992), a statistically significant $10 \%$ abnormal loss for the shareholders of the acquiring company over the holding period of 5 years was found; median negative return equalled $7.5 \%$. 
An extensive meta-analysis of research literature on synergies resulting from acquisitions (Homberg et al., 2009) established that the principal reason of M\&A transaction failures is the misevaluation of the potential synergies; even in the case of the relatedness of the acquirer and the acquiree the synergies are negligible and the abnormal rate of return for the acquirer's shareholders is negative.

A study by Rahman and Lambkin (2015) state that acquisitions may achieve some of the intended marketing goals, namely increase the revenue growth rate. Additionally, the sampled companies have decreased administrative and marketing expenses as a percentage of revenue; however, overall, the return on sales for the acquirer fell.

Extensive analysis of the M\&A performance in the ASEAN region (Rao-Nicholson et al., 2015) confirms that during the periods of economic growth M\&A transactions tend to have a negative influence on the operating performance of the acquirers, however, under conditions of economic turmoil acquisitions provide additional resources allowing the acquirers to better adapt themselves to a highly volatile environment.

To sum up, the second conjecture was partly proved as the results of critical review of empirical literature clearly suggest that the acquisitions lead to the negative long-term performance of the acquirer's stock. On the other hand, the performance of IPOs is inconsistent with expectations which are at odds with the conjecture. The post-IPO operating performance may decline suggesting that the expectations of the shareholders have not been met. However, empirical evidence indicates that the phenomenon of IPO long-term underperformance may have a behavioural origin. The behavioural factors play an important role in choosing the timing of the IPOs, determining the expectations and, as a result, in the medium- and long-term performance of the stocks.

\section{The Second Conjecture: Behavioural Explanation of IPO Underperformance}

Following the logic of Akerlof's model, the IPOs should perform in line with expectations and assure positive returns to the equity holders. However, empirical research (Jain, Kini, 1994; Ritter, 1991) found that IPOs are significantly underperforming in the long run compared to the benchmarks. This constitutes a violation of the Efficient Market Hypothesis, suggesting that the phenomenon might be explained by the factor of information asymmetry and behavioural deviations.

Ljungqvist et al. (2006) developed a model of IPO pricing which reconciles the IPO under-pricing and long-term underperformance. The basic premise, which shapes the theoretical framework of the model, is that some of the market participants are irrationally exuberant about a particular market. The developed model has several practical implications: 1) stocks of the companies which organize an IPO on a hot market (willing to benefit from the overvaluation of stocks in the industry in question) will inevitably underperform in the long run; 2) growing influence of the irrationally exuberant investors makes the IPO 
price deviate further from the fundamental value and causes the long-term performance to worsen; as the market is getting 'hotter' companies have more incentives to go public, which indicates a problem of the momentum effect and information asymmetry between investors and company management. Such an explanation called 'the window of opportunity' allows to explain all the pricing anomalies on the IPO market. The theoretical hypothesis of 'window of opportunities was validated on the data from the dotcom bubble period: the stocks of the IT companies which went public during the bubble formation period were significantly underperforming in a 3 to 5 year timeframe (Derrien, 2005).

\section{Management Hubris as a Reason for Exuberant Acquisition Premiums}

Transferring further Akerlof's line of reasoning to the logic of the acquisition process, one should assume that the potential acquirers, who anticipate that the acquired company may turn out to be a 'lemon', would incorporate the risks into the offer price (it happens to the prices of used cars as buyers' adjust to the diminished expected quality level). However, in practice, $M \& A$ transactions are often concluded with a premium well above the valuation of the target (Roll, 1986).

The explanation for this phenomenon, as well as for previously discussed market anomalies inherent in the IPOs market, relies on the combination of methodological assumptions of market efficiency and investors' rationality. Four approaches are possible: 1) we assume that rational investors are making decisions on perfectly efficient markets (Fama, 1970); 2) rational investors are acting on imperfect markets with information asymmetry (which is the case described by Akerlof); 3) irrational investors are dealing on perfectly efficient markets with complete information transparency (Ljungqvist et al., 2006); 4) irrational investors are making decisions on imperfect markets under conditions of uncertainty (observed in practice). The factor of information asymmetry combined with the assumption of investors' irrationality clarifies the commonly observed deviations from theoretical models.

The hubris hypothesis of corporate takeovers (Roll, 1986) offers an explanation of the excessive premiums paid by bidders'. A significant departure of the offer price from the target's market value suggests that it is at least partly a consequence of value transfer from the acquirer to the target. Roll (1986) clarifies that the process of target valuation, which often relies on material non-public information, incorporates the assessment of the expected synergies and a discount for flaws in the current management of the company. Such a value estimate can be treated as a random variable with the expected value equal to the current market valuation of the target, which constitutes the lower boundary of the potential offer price. If the managers assume that the market price is lower than the intrinsic value of the target, an acquisition deal will be consummated. Under the assumption of market efficiency, hubris becomes the only explanation of the acquisition premiums, which represent errors in valuation. Roll (1986) recognizes that the empirical evidence does not allow to reject the hubris hypothesis. 
Additional explanation of the bidding premiums is offered by the agency theory (Jensen, 1986). When a mature company, which is running out of attractive investment opportunities, is generating a substantial cash flow, management may, contrary to the interest of the shareholders, engage into value-destroying projects and conclude acquisition deals pursuing the goal of 'empire-building'.

\section{Dual-Track IPOs as a Market Solution to the Problem of Information Asymmetry}

Dual-track IPOs, which are gaining in popularity, offer increased flexibility in terms of exit options for private companies at a higher cost: the strategy consists in negotiating a potential M\&A deal while arranging all the legal formalities for an IPO.

The principal advantage of the dual-track IPO is that it allows eliminating the information asymmetry problem and fully benefiting from the current market conjuncture. At the same time, it offers an opportunity to exploit all the market imperfections described in the paper. Since empirical evidence (Bayar \& Chemmanur, 2012) suggests that IPOs offer a higher valuation premium, an acquisition may be contemplated as an additional option reserved for the case if the company misses the 'window of opportunity' and the owners want to sell their entire interest. If the current owners want to retain control over the company, the IPO will eventually be chosen, but running the M\&A track may increase interest to the company in the meanwhile, causing a significant oversubscription of the IPO and, as a consequence, a considerable premium.

Arrangements for an IPO may signal potential bidders that a company is expected to generate significant value-added in the future, and may entice the acquirers to increase the offered price to the level, which compensates the current owners for the benefits of control and potential synergies resulting from the acquisition. Taking into account the scope of the management hubris problem, such a premium may end up being significantly higher than the intrinsic value of the target.

\section{Conclusions}

This paper has attempted to explain the IPO valuation premium puzzle by the factor of information asymmetry. Relatively higher valuation premiums obtained through an IPO can be justified using the theoretical model developed by Akerlof (1970). A critical review of the empirical literature partially validates the conjectures derived from the developed theoretical framework. At the same time, several significant deviations (long-term IPO underperformance; exuberant acquisition premiums) are observed in practice, which may be explained by the influence of behavioural factors. 


\section{References}

Agrawal A., Jaffe J., Mandelker D. (1992), The post-merger performance of the acquiring firms: a re-examination of an anomaly, "The Journal of Finance" vol. 47, no. 4, pp. 1605-1621.

Akerlof G. (1970), The market for 'lemons': quality uncertainty and the market mechanism, "The Quarterly Journal Economics" vol. 84, no. 3, pp. 488-500.

Ang J., Boyer C. (2009), Performance differences between IPOs in new industries and IPOs in established industries, "Managerial Finance" vol. 35, no. 7, pp. 606-623.

Asquith P. (1983), Merger bids, uncertainty, and stockholder returns, "Journal of Financial Economics" vol. 11, pp. 51-83.

Ball E., Chiu H., Smith K. (2011), Can VCs time the market? An analysis of exit choice for venture-backed firms, "The Review of Financial Studies" vol. 24, no. 9, pp. 3105-3138.

Bayar O., Chemmanur T. (2012), What drives the valuation premium in IPOs versus acquisitions? An empirical analysis, "Journal of Corporate Finance" vol. 18, pp. 451-475.

Derrien F. (2005), IPO pricing in 'hot' market conditions: who leaves money on the table? "Journal of Finance" vol. 60 , pp. 487-521.

Fama E. (1970), Efficient capital markets: a review of theory and empirical work, "Journal of Finance" vol. 25, no. 2, pp. 383-417.

Gao X., Ritter J., Zhu Z. (2011), Where have all the IPOs gone?, Working Paper, University of Florida.

Homberg F., Rost K., Osterloh M. (2009), Do synergies exist in related acquisitions? A meta-analysis of acquisition studies, "Review of Managerial Science" vol. 3, pp. 75-116.

Jain D., Kini O. (1994), The post-issue operating performance of IPO firms, "The Journal of Finance” vol. 49, no. 5, pp. $1699-1726$.

Jensen M. (1986), Agency costs of free cash flow, corporate finance, and takeovers, "American Economic Review" vol. 76, pp. 326-9.

Jensen M., Ruback R. (1983), The market for corporate control: the scientific evidence, "Journal of Financial Economics" vol. 11 , pp. 5-50.

Kim M., Ritter J. (1999), Valuing IPOs, “Journal of Financial Economics” vol. 53, no. 3, pp. $409-437$.

Leland H., Pyle D. (1977), Information asymmetries, financial structure, and financial intermediation, "Journal of Finance" vol. 32, no. 2, pp. 371-387.

Ljungqvist A., Nanda V., Singh R. (2006), Hot markets, investor sentiment, and IPO pricing, "The Journal of Business" vol. 79, no. 4, pp. 1667-1702.

Poulsen A., Stegemoller M. (2008), Moving from private to public ownership: selling out to public firms versus initial public offerings, "Financial Management" vol. 37, no. 1, pp. 81-101.

Rahman M., Lambkin M. (2015), Creating or destroying value through mergers and acquisitions: a marketing persective, "Industrial Marketing Management" vol. 46, pp. 24-35.

Rao-Nicholson R., Salaber J., Cao T. (2015), Long-term performance of mergers and acquisitions in ASEAN countries, "Research in International Business and Finance" vol. 36, 373-387.

Ritter J. (1991), The long-run performance of initial public offerings, “Journal of Finance” vol. 46, pp. 3-27.

Roll R. (1986), The hubris hypothesis of corporate takeovers, “The Journal of Business” vol. 59, no. 2, pp. $197-216$.

\section{ANALIZA ANOMALII WYCENY PIERWOTNYCH OFERT PUBLICZNYCH: CZYNNIK ASYMETRII INFORMACJI}

Streszczenie: Bazując na wynikach badań empirycznych i modelu Akerlofa (1970), artykuł przedstawia wyjaśnienie anomalii wyceny ofert publicznych. Wybierając między pierwotną ofertą publiczną a przejęciem przez inną spółkę, coraz większa liczba firm wybiera tę ostatnią opcję, mimo że IPO potencjalnie oferuje wyższą premię cenową. Wnioski wyciągnięte na podstawie krytycznego przeglądu literatury empirycznej sugerują, że badane zjawisko jest spowodowane czynnikiem asymetrii informacji, co z kolei powoduje analogię z modelem Akerlofa, który pomaga wyjaśnić anomalię wyceny pierwotnych ofert publicznych. Jednak w praktyce są obserwowane znaczące odchylenia rezultatów firm sprzedawanych w ramach IPO od wniosków analizy normatywnej (gorsze w porównaniu do oczekiwań wskaźniki działalności operacyjnej; zbyt wysokie premie przy przęjęciach), które mogą być wywołane wpływem czynników behawioralnych. 
Przedstawione argumenty wskazują, że poprawność modeli teoretycznych analizowanych w artykule zależy od założeń odnośnie efektywności informacyjnej rynku finansowego oraz racjonalności jego uczestników. Artykuł zawiera również systematyzację tych założeń oraz prezentuje wnioski odnośnie ich trafności przy analizie przedstawionych anomalii wyceny, a także pokazuje, jak mechanizmy rynkowe takie jak 'dual-track’ IPO pomagają rozwiązać problem asymetrii informacji i wyeliminować anomalie wyceny.

Słowa kluczowe: anomalie wyceny pierwotnych ofert publicznych, przejęcie, asymetria informacji

\section{Citation}

Osiichuk D. (2016). Analysis of the IPO Valuation Premium Puzzle: the Factor of Information Asymmetry. Finanse, Rynki Finansowe, Ubezpieczenia, 1 (79), 113-123; www.wneiz.pl/frfu. 